\title{
The scientific method of Sir William Petty
}

\author{
JAMES H. ULLMER \\ Western Carolina University
}

\begin{abstract}
An understanding of the precise nature of the scientific method of Sir William Petty has proved elusive to historians of economic thought, in no small part because of a lack of Petty's own characterization of his scientific approach. This research clarifies the nature of Petty's method, as to whether it was primarily inductive or deductive, and to what extent it relied on empirical foundations. The paper employs a two-pronged analysis. First, it examines the main sources of Petty's method: the works of Sir Francis Bacon and Thomas Hobbes, and the synergistic influences of the Hartlib Circle, the Royal Society, the Dublin Philosophical Society, and the Mersenne group. Second, four of Petty's most noted contributions to political economy are deconstructed in order to identify his scientific method. This research concludes that Petty relied almost exclusively on deduction in his scientific approach and that his analysis does not reveal any inductive reasoning. When data was available, Petty constructed his economic theories on empirical foundations.
\end{abstract}

Keywords: deduction, empiricism, natural law, rationalism

JEL Classification: A11, B11, B31, B41

Sir Francis Bacon's (1561-1626) innovative scientific method was characterized by two distinct but related components: empiricism and inductive reasoning. With respect to the first element, he insisted upon empirical foundations for establishing new knowledge. Accordingly, Bacon writes in Book I, Aphorism LXXXII of Novum organum that "a method rightly ordered leads by an unbroken route through the woods of experience to the open ground of axioms" (Bacon [1620] 1963, vol. 4, 81). With respect to the inductive element of his scientific method, in a letter to King James I of England, dated October 12, 1620, Bacon writes: "The work [...] is no more than a new logic, teaching to

AUTHOR's NoTE: I am grateful to my sister, Jean Bailly, for her valuable suggestions and editorial comments. I would also like to thank the anonymous referees and an editor of this journal, François Claveau, for their helpful comments. Finally, I appreciate the generosity of the Thompson Library at Ohio State University in lending me an electronic copy of the Hartlib papers (Hartlib 2002). 
judge and invent by induction, (as finding syllogism incompetent for sciences of nature)" (Bacon [1620] 1963, vol. 14, 119-120; emphasis added).

Sir William Petty's (1623-1687) scientific method, at least in his own estimation, was the unvarnished scientific approach developed and promoted by Sir Francis Bacon in the late 16th and early 17th centuries. Petty's description of his scientific technique, which he terms "political arithmetic", is unambiguous as to its empirical foundations, as set forth in the following well-known passage:

The Method I take to do this, is not yet very usual; for instead of using only comparative and superlative Words, and intellectual Arguments, I have taken the course [...] to express my self in Terms of Number, Weight or Measure; to use only Arguments of Sense, and to consider only such Causes, as have visible Foundations in Nature; leaving those that depend upon the mutable Minds, Opinions, Appetites, and Passions of particular Men, to the Considerations of others" (Petty [1690] 1899, 244; emphasis in original). ${ }^{1}$

The statement cited above does not allude to any element of induction in his scientific approach, and there has been confusion and disagreement among historians of economic thought on how to characterize Petty's scientific method. Mary Poovey, for example, notes the influence of Thomas Hobbes (1588-1679) on Petty, and describes Petty's scientific method as a "complex theoretical amalgam [...] [that was arrived at] by mixing Baconian induction with Hobbesian deduction" (Poovey 1998, xviii). ${ }^{2}$ On the other hand, Tony Aspromourgos insists that "Petty was an empiricist", but does not concur that Petty was "an inductivist" (Aspromourgos 1996, 57). This confusion in the scholarly literature motivated me to investigate and analyze Petty's scientific method in order to determine where and to what extent his approach mirrored the scientific methods of Bacon and Hobbes.

The purpose of this article is thus to clarify the scientific method of William Petty, its complexity, subtlety and, for that time, novelty. First, I offer a synopsis of the respective scientific methods of the two seminal influences on Petty: Bacon and Hobbes. Second, I describe and trace the

\footnotetext{
${ }^{1}$ Using Petty's Discourse on duplicate proportion ([1674] 1969), Robert Kargon presents an insightful illustration of Petty's scientific method as employed in natural science (Kargon 1965). Here, Petty's use of the experimental approach is evident.

${ }^{2}$ Quentin Skinner, while discussing the intellectual impact of Hobbes, includes William Petty as one of several European scholars of the mid seventeenth-century who were influenced by him (Skinner 1966).
} 
intellectual sources of Petty's scientific method. Third, I explain Petty's method by articulating the scientific approach he most likely employed to arrive at four of his most noted contributions to political economy: his pioneering development of national income accounting; his theory of the velocity of money; theory of value; and theory of the rate of interest. Finally, I conclude that Petty relied almost exclusively on deduction in his economic analysis, and as Aspromourgos claims, there is no evidence of inductive reasoning in Petty's method. His economic theories had an empirical component when data was available.

\section{BACON'S SCIENTIFIC METHOD}

Sir Francis Bacon claimed that his new empirical and inductive method could reveal the entire universe of knowledge. In The advancement of learning, Bacon provided a glimpse of the three broad areas of natural history his method would enlighten: "History of Nature is of three sorts; of nature in course, of nature erring or varying, and of nature altered or wrought; that is, history of Creatures, history of Marvels, and history of Arts" (Bacon [1605] 1963, vol. 3, 330).

Subsequently, Bacon dichotomizes the study of natural history into two types in the following passage from The great instauration:

Next, with regard to the mass and composition of it [natural history]: I mean it to be a history not only of nature free and at large [...] but much more of nature under constraint and vexed; that is to say, when by art and the hand of man she is forced out of her natural state, and squeezed and molded. Therefore I set down at length all experiments of the mechanical arts [...] seeing that the nature of things betrays itself more readily under the vexation of art than in its natural freedom (Bacon [1620] 1963, vol. 4, 29).

Here we see that Bacon believed that the study of the mechanical arts would prove more useful because nature more clearly reveals herself when under constraint. This led Bacon to favor experimentation under controlled conditions as a vehicle for acquiring new knowledge.

Precisely how then did Bacon propose to discover new scientific knowledge? Contrasting his new scientific method with the old Aristotelian approach, Bacon argued for the superiority of his new scientific technique in Aphorism XIX in Book I of Novum organum:

There are and can be only two ways of searching into and discovering truth. The one flies from the senses and particulars 
to the most general axioms, and from these principles, the truth of which it takes for settled and immovable, proceeds to judgment and to the discovery of middle axioms. And this way is now in fashion. The other derives axioms from the senses and particulars, rising by a gradual and unbroken ascent, so that it arrives [inductively] at the most general axioms last of all. This is the true way, but as yet untried (Bacon [1620] 1963, vol. 4, 50).

To Bacon, new knowledge should rest solidly on empirical foundations and should not be deduced from a priori premises. In Aphorism LXXXII, Book I of Novum organum, he writes that:

[...] the true method of experience on the contrary first lights the candle, and then by means of the candle shows the way; commencing as it does with experience duly ordered and digested, not bungling or erratic, and from it [d]educing axioms, and from established axioms again new experiments (Bacon [1620] 1963, vol. 4,81$)$.

Finally, Bacon did not limit the scope of his scientific inquiry to natural history alone. His insistence that his scientific method was also applicable to the social and civil sciences is reflected in Aphorism CXXVII, Book I of Novum organum:

It may also be asked [...] whether I speak of natural philosophy only, or whether I mean that the other sciences, logic, ethics, and politics, should be carried on by this method. Now I certainly mean what I have said to be understood of them all; and as the common logic, which governs by the syllogism, extends not only to natural but to all sciences; so does mine also, which proceeds by induction, embrace everything (Bacon [1620] 1963, vol. 4, 112).

\section{HOBBES'S SCIENTIFIC METHOD}

Karl Marx (1818-1883) and Frederick Engels (1820-1895) identified Bacon as "[t]he real founder of English Materialism and all modern experimental science" (Marx and Engels [1845] 1956, 172; emphasis in original). They went on to assert that "Hobbes systematized Bacon" (p. 173). But Hobbes did far more than "systematize" Bacon's work. He developed a method that differed from Bacon's; one that relied mainly on deduction from a priori premises. In Elements of philosophy, Hobbes characterizes his scientific approach as follows: 
Analysis is continual reasoning from the definitions of the terms of a proposition we suppose true, and again from the definitions of the terms of those definitions, and so on, till we come to some things known, the composition whereof is the demonstration of the truth or falsity of the first supposition, and this composition or demonstration is that we call Synthesis. Analytica, therefore, is that art, by which our reason proceeds from something proposed, to principles, that is, to prime propositions, or to such as are known by these, till we have so many propositions as are sufficient for the demonstration of the truth or falsity of the thing supposed. Synthetica is the art itself of demonstration. Synthesis, therefore, and analysis, differ in nothing, but in proceeding forwards or backwards; and Logistica comprehends both (Hobbes [1655] 1966, vol. 1, 309-310; emphasis in original).

Hobbes was a rationalist in that he believed that human reasoning was an essential element of all new scientific knowledge. To Hobbes, science involved a dynamic reasoning process which moved both from effects to their causes and from causes to their effects. In Elements of philosophy, Hobbes put it as follows: "METHOD, therefore, in the study of philosophy, is the shortest way of finding out effects by their known causes, or of causes by their known effects" (Hobbes [1655] 1966, vol. 1, 66; emphasis in original). Expounding further on his scientific method, he writes that:

[...] in the searching out of causes, there is need partly of the analytical, and partly of the synthetical method; of the analytical, to conceive how circumstances conduce severally to the production of effects; and of the synthetical, for the adding together and compounding of what they can effect singly by themselves (Hobbes [1655] 1966, vol. 1, 79).

David G. James notes that of the "two processes, moving forward from cause to effect, or going backward from effect to cause, Hobbes clearly gives first place to the former" (James 1949, 14). In the former approach, principles are first established and defined, and then effects based on those propositions are demonstrated. In the latter procedure, scientists "enquire into the causes of some determined experience [...] as what is the cause of light, of heat, of gravity [...] and the like" (Hobbes [1655] 1966, vol. 1, 68; emphasis in original). Hobbes believed that the causes thus identified for these phenomena may or may not be their true causes. "Thus Hobbes accepts the Aristotelian idea that to 
have the best sort of knowledge, scientific knowledge, is to know something through its causes" (Duncan 2009).

Consistent with his rationalist philosophy, Hobbes sought to generalize and apply the rigorous deductive methods of geometry to all science. In this regard, Richard A. Talaska notes that Hobbes's scientific method "consists in the correct approach and application of the rules of syllogism to propositions in order to generate new knowledge by systematically connecting primary with non-primary propositions" (Talaska 1988, 209). Thus, for example, Hobbes writes: "The definition, therefore, of a demonstration is this, a demonstration is a syllogism, or series of syllogisms, derived and continued, from the definition of names, to the last conclusion" (Hobbes [1655] 1966, vol. 1, 186; emphasis in original). That is, Hobbes emphasized the use of the deductive method, as employed in Euclidean geometry, to establish hypotheses that could then be demonstrated synthetically.

In addition to his reliance on the deductive method, Hobbes's scientific approach is characterized by his belief in natural law. In Chapter XIV of Leviathan, Hobbes defines a law of nature as "a precept, or general rule, found out by reason, by which a man is forbidden to do that, which is destructive of his life, or taketh away the means of preserving the same" (Hobbes [1651] 1966, vol. 3, 116-117). Applying this concept to the state, he writes in De corpore politico that "there can therefore be no other law of nature than reason, nor no other precepts of natural law, than those which declare unto us the ways of peace, where the same may be obtained, and of defense where it may not" (Hobbes [1655] 1966, vol. 4, 87; emphasis in original). Arguing that natural laws were indeed properly in the realm of science, Hobbes writes that "[t]hese dictates of reason, men used to call by the name of lawes, but improperly: for they are but conclusions, or theorems concerning what conduceth to the conservation and defence of themselves" (Hobbes [1651] 1966, vol. 3, 147; emphasis added). Thus, to Hobbes, laws of nature were certain rules understood by reason, relating to selfpreservation and social peace.

Finally, Hobbes not only believed civil science was a proper domain for his method, but believed that the hypotheses asserted in civil science were more capable of producing true conclusions than hypotheses in natural science because they could be demonstrated. Accordingly, in his Dedication to Six lessons, he writes that "civil philosophy is demonstrable, because we make the commonwealth 
ourselves. But because of natural bodies we know not the construction, but seek it from the effects, there lies no demonstration of what the causes be we seek for, but only of what they might be" (Hobbes [1656] 1866, vol. 7,184$)$. Hobbes believed that demonstrable certainty was only possible in geometry and civil philosophy because much like man creates geometric figures, he also creates Leviathan. Hence, Sacksteder insightfully notes that to Hobbes "civil philosophy [...] much as geometry is demonstrable because the lines and figures are drawn by ourselves rather than by nature" (Sacksteder 1980, 146).

\section{SOURCES OF PETTY'S METHOD}

Samuel Hartlib (c1600-1662), a fervent disciple of Bacon, immigrated to England from Poland in 1628. Like many second generation Baconians, he was eager to apply and to spread Bacon's method (Letwin [1963] 1975, 124). To that end, Hartlib joined together through correspondence a group of European intellectuals "now known as the 'Hartlib Circle' [...] a diverse and self-selecting group of [...] 'ingenui', whose interests [...] were supported by a shared viewpoint in which the potential of free and 'real' knowledge [could] benefit the commonwealth" (Hartlib 2002, Introduction). Petty was an important member of the Hartlib Circle, which sought to implement the Baconian method in the interest of increasing practical knowledge in all branches of science for the benefit of mankind. ${ }^{3}$ In a 1648 Epistle entitled The advice of W. P. to Mr. Samuel Hartlib for the advancement of some particular parts of learning, Petty articulates this goal:

To give an exact Definition or nice Division of Learning, or of the Advancement thereof, we shall undertake (it being already so accurately done by the great Lord Veralum [Bacon]) [i]ntending onely [...] to point at some pieces of Knowledge, the improvement whereof [...] would make much to the generall good and comfort of all mankind, and withall to deliver our own opinion by what meanes they [pieces of knowledge] may be raised some degree neerer to perfection (Petty [1648a] 1990, 1; emphasis in original).

In his conclusion to the same tract, Petty elaborates:

\footnotetext{
3 For a more complete description of the Hartlib Circle and their efforts see Rattansi 1968, 130-137; Webster 1970; Webster 1975; Hunter 1985, 24-25; Vickers 1987, 5; McCormick 2009, 41-44.
} 
The next Booke which we recommend is the History of Nature free, for indeed the History of Trades is also an History of Nature, but of Nature vexed and disturbed. What we meane by this History, may be known by the Lord Veralums most excellent Specimen thereof, and as for the particulars it should treat on, we referre to his Exact and Judicious Catalogue of them, at the end of his Advancement of Learning (Petty [1648a] 1990, 26; emphasis in original).

Carl Wennerlind claims that "[a]rguably the most influential disseminator of the Baconian research project was the Hartlib Circle" (Wennerlind 2003, 246). He states that:

[The] Hartlib Circle or the 'invisible college', as it was also known, served as a link between Gresham College-the first systematic effort in England to apply scientific lessons to the practical affairs of the state and the demands of commercial expansion-and the Royal Society [of which Petty was a founding Fellow] (Wennerlind 2003, 246).

Petty was also a founding member and first President of the Dublin Philosophical Society, established in 1683. Tony Barnard writes that "it was Petty who linked the Hartlib Circle with the Dublin Philosophical Society. [...] Petty's career epitomized the successful application of Hartlibian principles" (Barnard 1974, 67). One important Hartlibian principle was to establish a Baconian "program of systematic artificial experimentation" (Shapin 2010, 62) to advance science. Accordingly, Barnard claims that, as President of the Philosophical Society, Petty "drafted rules [...] which, if adopted, would have produced greater emphasis on experiment" (Barnard 1974, 67). Interestingly, Petty's experimental bent is in direct opposition to Hobbes, who was vehemently opposed to the experimental method employed by the Royal Society. ${ }^{4}$

Petty's advocacy of the experimental method is most clearly stated in a letter to Henry More sent via Hartlib (McCormick 2009, 61). In this

\footnotetext{
${ }^{4}$ In their compelling monograph, Leviathan and the air-pump: Hobbes, Boyle, and the experimental life (1985), Shapin and Schaffer present a central disagreement in the history of science between Robert Boyle (1627-1692), a founding member of the Royal Society, and Hobbes over the proper scientific method. Boyle, in accordance with Hartlibian principles, favored the experimental method in the quest for new knowledge. Hobbes viewed the experimental method as contrived, and therefore, unreliable. The notion "of a fertile union of principles and experiment was lost on Hobbes" (James 1949, 14).
} 
1648 correspondence, Petty objects to More's endorsement of the Cartesian approach and proposes the following:

I wish therefore that the great wits of theses times would employ themselves in collecting \& setting down in good order \& Method all [...] Experiments \& not bee too buisy in making inferences from them till some Volumes of that Nature are compiled, then wee should have a judge of our controversies and when wee can finde such principles or axioms as will stand with all these Experiments they may right bee [...] [accounted] \& admitted as such (Petty [1648b] 2002, 123).

This letter demonstrates that Petty, in accordance with Baconian scientific method, later reflected in Hartlibian principles, advocated the use of empirical information gathered from successive experiments to reach general principles or axioms. Subsequently, Petty demonstrated these beliefs through his active participation in the Royal Society and the Dublin Philosophical Society.

Petty visited mainland Europe from 1636 to 1639, and again from 1643 to $1648 .^{5}$ Petty's first visit to mainland Europe was entirely accidental. In 1636 as a ship's boy on a merchant ship, he suffered a broken leg and was put ashore at Caen on the French coast (Masson and Youngson 1960, 81). ${ }^{6}$ Hull recounts that "this twist of fate left the young Petty to shift for himself; he recounted his misfortune in Latin so well that the Jesuit fathers of Caen not only cared for him but admitted him as a pupil in their college" (Hull 1899, vol. 1, iv). Petty's earliest encounter with deductive logic probably occurred as a student reading Euclid at the Jesuit College in Caen, the first continental influence on his thought. Petty's textbook may well have been the 1589 edition of Euclid's Elements by Christopher Clavius (1538-1612), which "may also have been the book that converted Thomas Hobbes to the deductive method of geometrical demonstration" (McCormick 2009, 26).

In 1643, "when the civil war betwixt the King and Parliament grew hot", Petty joined the army of English refugees in the Netherlands and "'vigorously followed his studies, especially that of medicine', at Utrecht, Leyden and Amsterdam" (Hull 1899, vol. 1, xiv). By November of 1645, Petty had made his way to Paris, where he lived until his return to

\footnotetext{
${ }^{5}$ See McCormick (2009, 14-39) for a brief historical account.

${ }^{6}$ Aubrey recounts that Petty informed him in conversation that at about twelve or thirteen he experienced "the most remarkable accident of life (which he did not tell me), and which was the foundation of all the rest of his greatness and acquiring riches" (Aubrey 1983, 242; original emphasis deleted). This is the event that Petty is most likely referring to.
} 
England in 1648. During his time in Paris, Petty became associated with Hobbes. Thus, the well known link between Petty and Hobbes began early in Petty's career. ${ }^{7}$ Just as Hobbes had been employed as an amateur secretary by Francis Bacon, Hobbes now employed Petty to assist him in his study of anatomy (Strauss 1954, 28). Petty's study of anatomy on the continent, especially under Hobbes, was influential to his thinking about political economy. In this regard, Ludovic Desmedt insightfully notes that "[w]hile medicine was discovering certain physiological principles, political economy was being developed by [these same] physicians or professors of anatomy" (Desmedt 2005, 80).

Hobbes, who resided in Paris from 1640-1651, was also a prominent member of a group of mathematician-scientists and philosophers, known collectively as the Mersenne group. ${ }^{8}$ Marin Mersenne (1588-1648) "was central to the new mathematical approach to nature in Paris in the 1630s and 1640s. [...] [and was the primary scholar who] put thinkers from all over Europe sympathetic with the new science in touch with one another" (Garber 2004, 136). Through his association with Hobbes, Petty gained access to these eminent scholars. Thirty years later he acknowledged his intellectual debt to them. In the Dedicatory to the Lord Duke of Newcastle in his Discourse on duplicate proportion, which he presented to the Royal Society on November 26, 1674, Petty writes:

[...] because your Grace doth not onely love(s) the search of Truth, but did encourage Me 30 years ago as to Enquiries of this kind. For about that time in Paris, Mersenne, Gassendy (1592-1655), Mr. Hobs, Monsieur Des Cartes (1595-1650), Monsieur Roberval (1602-1675), Monsieur Mydorge (1585-1647) and other famous men [...] [who] did countenance and influence my Studies, as well by their Conversation as their Publick Lectures and Writings (Petty [1674] 1969, Dedicatory Epistle; emphasis deleted).

We thus see that the deductive aspect of Petty's scientific method owes much to his experiences on the continent, first in his studies with the Jesuits at Caen and then in his study and work with Hobbes and the Mersenne group in Paris.

\footnotetext{
7 "Throughout his life Petty remained a sincere admirer of Hobbes's genius" (Strauss 1954, 29) and a "great friend" of him (Aubrey 1983, 160). Indicative of that, Petty-writing shortly before his death-included Hobbes's De cive in a short list of books he wished his sons to read (see Fitzmaurice 1895, 303).

${ }^{8}$ For a thorough treatment of the intellectual contributions of Marin Mersenne and the other scholars who made up the Mersenne group, refer to Mersenne and the learning of the schools (Dear 1988).
} 
Hobbes's influence can also be seen in Petty's embrace and utilization of the concept of natural law in his own method, particularly as applied to political economy. While Bacon believed that civil science was appropriately suited to his scientific method, his followers-the experimentalists of the Royal Society-felt that there should be a strict separation between the practice of natural science and civil science. Shapin and Schaeffer maintain that this notion was the result of:

[The Royal Society's] evaluation of the capacity of each [branch of science] to secure consensus and assent. Through the matter of fact, experimental natural philosophy could mobilize effective consensus [...] [while it was claimed] civic philosophy might sow the seeds of division, which would, inevitably, infect the practice of natural philosophy (Shapin and Schaeffer 1985, 153).

Petty disagreed with the Royal Society in this and avidly applied his method to political economy. Petty's scientific work in this realm clearly shows that he shared Hobbes's view that because the commonwealth was man-made, propositions in civil science were highly demonstrable, and therefore quite capable of achieving consensus and assent.

\section{ARTICUlation OF PETTY's METHOD}

William Petty's most specific comment concerning his method is contained in Political arithmetic where he proposes to express himself "in terms of Numbers, Weight or Measure" (Petty [1690] 1899, 244; emphasis in original). However, not being a philosopher like Bacon or Hobbes, Petty does not articulate his scientific method explicitly in his writings. To explain his method I have worked backward from an examination of his four most significant contributions to political economy-his pioneering efforts in national income accounting; his theory of the velocity of money; theory of value; and theory of the rate of interest-to the probable processes he used to arrive at them.

Petty was a pioneer of national income accounting. His analysis rests on the empirical information contained in a work by his friend John Graunt (1620-1674), the Natural and political observations, mentioned in a following index, and made upon the bills of mortality (Graunt 1662). ${ }^{9}$ Petty presents his analysis in the first two chapters of Verbum sapienti,

\footnotetext{
${ }^{9}$ There has been some dispute as to whether Petty was the actual author of the Natural and political observations or merely a contributor. For a discussion of the disputed authorship, which concludes in the negative, see Hull 1899, xxxix-liv; Groenewegen 1967, 601-602; McCormick 2009, 131-132.
} 
which was appended to the Political anatomy of Ireland when posthumously published in 1691.

He begins his inquiry by estimating the total annual expenditures in England and Wales on the basis of population and per-capita spending:

There are of Men, Women and Children, in England and Wales, about six Millions, whose Expense at 6£. 13s. 4d. per Annum [...] for Food, Housing, Cloaths, and all other necessaries, amount to 40 Millions per Annum (Petty [1691] 1899, 105; emphasis deleted).

Petty assumes that national income equals national expenditures, and therefore, national income is also $£ 40$ million. He then estimates "what would be termed today the 'non-human wealth' of England and Wales" (Thornton 2009, 34). Non-human wealth consists of land and five smaller stocks of wealth-housing, shipping, cattle, goods, gold, and silver. He approximates the wealth in land to be $£ 144$ million and the wealth contained in the five smaller stocks of wealth to be $£ 106$ million for a total of $£ 250$ million in non-human wealth (Petty [1691] 1899, 105-107).

Petty theorizes that the stock of wealth generates a nation's national income. He then summarizes his estimates of national income generated by the various stocks of non-human wealth with the following:

Now if the Land worth 144 Millions, yield 8 Millions per annum, the other Estate converted into like Species must yield 5 8/9 more; but because Money and other personal Estates yield more per annum than Land [...] then instead of $58 / 9$, suppose it to yield 7 , making the whole Annual Proceed 15 (Petty [1691] 1899, 108; emphasis deleted).

Having calculated the income from non-human wealth, Petty next postulates that "if the Annual proceed of the Stock, or Wealth of the Nation, yields but 15 millions, and the expence be 40 [...] Then the labour of the People must furnish the other 25" (Petty [1691] 1899, 108). He concludes that: "Whereas the Stock of the Kingdom, yielding but 15 Millions of proceed, is worth 250 Millions; then the People who yield 25, are worth 416 2/3 Millions" (Petty [1691] 1899, 108).

We see here that Petty's national income accounting analysis rested firmly on empirical foundations in the form of the data contained in Graunt's (1662) Natural and political observations. His inquiry also relied on two important assumptions: national income is equal to national 
expenditure, and national income flows from national wealth. From the population data and his two premises, Petty was able to estimate national wealth and the streams of national income that flowed from those stocks. Hence, Petty's inquiry into national income accounting is an example of his employing both Baconian empiricism and Hobbesian deduction.

Petty articulates his theory of the velocity of money in the context of ascertaining whether or not there was sufficient money to sustain the trade of England. Accordingly, in chapter 5 of Verbum sapienti, he writes:

It may be asked, If there were occasion to raise 4 Millions per Annum, whether the same six Millions (which we hope we have) would suffice for such revolutions and circulations thereof as Trade requires? I answer yes; for the Expense being 40 Millions, if the revolutions were in such short Circles, viz. weekly, as happens among poorer artizans and labourers, who receive and pay every Saturday, then 40/52 parts of 1 Million of Money would answer those ends: But if Circles be quarterly, according to our Custom of paying rent, and gathering Taxes, then 10 Millions were requisite. Wherefore supposing payments in general to be of a mixed Circle between One week and 13 then add 19 Millions to 40/52, the half of which will be $5-1 / 2$, so as we have $51 / 2$ Millions we have enough (Petty, [1691] 1899, 112-113; emphasis deleted).

On the basis of his theory of the velocity of money, Petty reaches two conclusions. First, the velocity of money is inversely related to payment periods. Second, he deduces that if one knows the size of the money stock and its velocity, one can then determine the volume of trade that could be supported by that money supply. Petty subsequently proceeds to illustrate his proposition hypothetically by estimating the requisite money supply necessary to support the trade of England on the basis of different velocities of money. In the above example, for an economy with a trade of $\$ 40$ million, if payments were quarterly, velocity would be four and $£ 10$ million would be sufficient. Despite Petty's methodological claim "to use only Arguments of Sense" (Petty [1690] 1899, 244), his formulation of the theory of the velocity of money relies on the deductive approach of the Hobbesian scientific method. 
Petty's theory of value is introduced in A treatise of taxes and contributions. ${ }^{10}$ He begins his theory with the following:

Suppose a man could with his own hands plant a certain scope of Land with Corn, that is, could Digg, or Plough, Harrow, Weed, Reap, Carry home, Thresh, and Winnow so much the Husbandry of this Land requires; and had withal Seed wherewith to sowe the same. I say, that when this man hath subducted his seed out of the proceed of his Harvest, and also, what himself hath both eaten and given to others in exchange for Clothes, and other Natural necessaries; that the remainder of the Corn is the natural and true Rent of the Land for that year (Petty [1662] 1899, 43).

Thus, Petty defines the natural rent of land as the value of corn that labor, after being fairly compensated, is able to produce.

In concluding the exposition of his theory of value, Petty compares the value of the corn produced by that individual farmer to the value of silver that could be created by an individual miner:

Let another man go travel into a Countrey where is Silver, there Dig it, Refine it, bring it to the same place where the other man planted his Corn; Coyne it, \&c. the same person, all the while of his working for Silver, gathering also food for his necessary livelihood, and procuring himself covering, \&c. I say, the Silver of the one, must be esteemed of equal value with the Corn of the other: the one being perhaps twenty Ounces and the other twenty Bushels. From whence it follows, that the price of a Bushel of this Corn to be [equal to] an Ounce of Silver (Petty [1662] 1899, 43; emphasis added).

Petty's objective theory of value could only have been postulated on a priori premises. Supposition one is that all goods have intrinsic value. Supposition two is that the relative value of goods could be measured by the surplus value created by labor in their production. He supplies evidence for his theory with the above example of corn and silver and then declares that the price of a bushel of corn would be equal to the price of an ounce of silver if the labor required to produce a bushel of corn was equal to the labor required to produce an ounce of silver. Here, in strictly employing the deductive method of rationalism, Petty's analysis is clearly Hobbesian.

\footnotetext{
${ }^{10}$ Although often characterized as a labor theory of value, Henry Spiegel notes that Petty's theory of value "is not an outright labor theory but one which places land and labor side by side" (Spiegel 1991, 128; emphasis added).
} 
Petty's descendant, Edmund Fitzmaurice (1872-1936), the sixth Marquis of Landsdowne, perceptively notes that "Petty, as his writings show, had a passion for definitions, imbibed perhaps through his early association with Hobbes" (Petty 1927, vol. 2, 149). Hence, not surprisingly, Petty's theory of the rate of interest begins with his definition that interest is "a compensation for [...] inconvenience" (Petty [1662] 1899, 47; emphasis added). Next, he asserts that the minimum amount the rate of interest can be "is the Rent of so much Land as the money lent will buy, where the security is undoubted" (Petty [1662] 1899, 48). Where repayment was insecure, risk "may advance the Usury very conscionably unto any height below the Principal it self" (Petty [1662] 1899, 48).

Petty groped toward a monetary theory of the rate of interest. It was based on two related premises. First, increases in the money supply result in lower rates of interest. Hence, Petty wrote that "the natural fall of Interest, is the effect of the increase of Mon[e]y" (Petty [1690] 1899, 304). Second, the presence of banks enhances the money supply. Thus, Petty notes in manuscript 68 of The Petty papers that "[w]here [b]anks are interest will be low" (Petty 1927, vol. 1, 246). ${ }^{11}$

While Petty's formulation of a monetary explanation for interest rates was radical in his time, his belief in natural law, which was shared by Hobbes and other seventeenth-century philosophers, was also an important underpinning for his analysis of the interest rate. ${ }^{12}$ Petty posited a principle of universal natural law, according to which citizens as economic actors are guided by the laws of nature. Petty warns not to legislate against natural law with the following: "But of the vanity and fruitlessness of making Civil Positive Laws against the Laws of Nature, I have spoken elsewhere, and instanced in several particulars" (Petty [1662] 1899, 48). ${ }^{13}$

Petty recognizes the fact that there are differences in interest rates among nations and attributes it to the different "[l]awes [...] of particular countries" (Petty 1927, vol. 1, 144). Accordingly, he ascribes

\footnotetext{
${ }^{11}$ Because Petty believed that banks were necessary to ensure liquidity, he proposed the establishment of land banks, whose security would be based on a national registry, to ensure adequate liquidity. For Example, Petty offered the following recommendation to James II: "[E]rect a Registry of Lands, which may [in] effect coyne lands into money" (Petty 1927, vol. 1, 257).

${ }^{12}$ For a thorough discussion of Petty and his notion that natural law governed human behavior, see Ullmer 2004, 404-408.

${ }^{13}$ Alfred Chalk notes that "in Petty's writings [...] his favorite thesis is that the natural laws of society are so powerful that they can never be circumvented by "positive" civil Laws" (Chalk 1951, 343).
} 
the disparate interest rates among European countries to the different policies of those countries concerning their banking systems. Hence, in describing policies that had made The Netherlands the most advanced economy of Europe at that time, Petty notes: "[The Netherlands'] third policy [for increasing trade] is their bank, the use whereof is to encrease $\mathrm{M}[\mathrm{o}]$ ney, or rather to make a small sum equivalent in Trade to a greater" (Petty [1690] 1899, 265). In other words, in countries like The Netherlands which had a more developed banking system, the portion of income deposited by citizens was enhanced by national policy and therefore the money supply was greater than in England, which then culminated in a lower rate of interest.

The above articulation of Petty's scientific method reveals that, despite Petty's claim that he was attempting to employ Bacon's novel, scientific approach, his pioneering efforts in political economy were more Hobbesian than Baconian. All of Petty's endeavors in economic theory included a significant element of deductive thinking and do not exhibit inductive reasoning. Only Petty's seminal efforts in national income accounting have an explicit empirical component. This is not surprising since economics was in a pre-paradigm situation in which "fact-gathering is a [...] nearly random activity [...] [and] fact-gathering is usually restricted to the wealth of data that lie ready at hand" (Kuhn [1962] 1970, 15). Indeed, the only data available to Petty was contained in Graunt's (1662) Natural and political observations. Petty's rudimentary use of "number, weight, or measure" in political economy set the precedent for the employment of empirical analysis in economics as data gathering became more formal and precise.

\section{CONCLUSION}

Sir William Petty's work was revolutionary in two ways. First, he employed a novel scientific method, in that he was an empiricist when data was available, and a rationalist who principally employed deduction in the pursuit of the underlying natural laws of political economy. Second, he applied his new method to an emerging discipline: economics.

The two seminal influences on the scientific method of Petty were Bacon and Hobbes. From Bacon, Petty inherited his empiricism. From Hobbes, who was a more significant influence on Petty, he drew his reliance on the deductive elements of rationalism. 
Petty's decision to apply his scientific methods to political economy, though partly a product of his own genius and predilections, was also inspired by Hobbes, who saw the potential for and described the application of his methods to the domain of civil science. ${ }^{14}$ Aspromourgos points out a significant difference, however, in the focus of their attention: whereas "Hobbes had devoted himself to determining the theoretical conditions for peace [...] Petty turned to the conditions required for prosperity" (Aspromourgos 1996, 17; emphasis added).

\section{REFERENCES}

Amati, Frank, and Tony Aspromourgos. 1985. Petty contra Hobbes: a previously untranslated manuscript. Journal of the History of Ideas, 46 (1): 127-132.

Aspromourgos, Tony. 1996. On the origins of classical economics: distribution and value from William Petty to Adam Smith. London: Routledge.

Aubrey, John. 1983. Brief lives, ed. Richard Barber. Totowa (NJ): Barnes and Noble Books.

Bacon, Francis. 1963. The works of Francis Bacon (fourteen volumes), eds. James Speeding, Robert L. Ellis, and Douglas D. Heath. Stuttgart-Bad Cannstatt: Friedrich Frommann Verlag-Günther Holzboog.

Barnard, Tony. 1974. The Hartlib Circle and the origins of the Dublin Philosophical Society. Irish Historical Studies, 19 (73): 56-71.

Chalk, Alfred F. 1951. Natural law and the rise of economic individualism in England. The Journal of Political Economy, 59 (4): 332-347.

Dear, Peter. 1988. Mersenne and the learning of the schools. Ithaca (NY): Cornell University Press.

Desmedt, Ludlovic. 2005. Money in the "Body Politic": the analysis of trade and circulation in the writings of seventeenth-century political arithmeticians. History of Political Economy, 37 (1): 79-101.

Duncan, Stewart. 2009. Thomas Hobbes. The Stanford Encyclopedia of Philosophy, ed. Edward N. Zalta. http://plato.stanford.edu/archives/spr2009/entries/hobbes/ (accessed 20 November 2011).

Fitzmaurice, Edmund. 1895. The life of Sir William Petty. London: Murray.

Garber, Daniel. 2004. On the frontiers of the scientific revolution: how Mersenne learned to love Galileo. Perspectives on Science, 12 (2): 135-163.

Graunt, John. 1662. Natural and political observations, mentioned in a following index, and made upon the bills of mortality. London: Printed by Thomas Roycroft for James Martyn, James Allestry, and Thomas Dicas.

Groenewegen, Peter D. 1967. Authorship of the Natural and political observations upon the bills of mortality. Journal of the History of Ideas, 28 (4): 601-602.

Hartlib, Samuel. 2002. The Hartlib papers. Sheffield: Humanities Research Online.

${ }^{14}$ A good example of the focus of Hobbes and Petty on political economy and their interaction in this domain is the manuscript "Petty contra Hobbes", in which Petty responds to Hobbes about which is the more desirable form of government, monarchy or democracy (see Amati and Aspromourgos 1985, 127-132). 
Hobbes, Thomas. 1966. The English works of Thomas Hobbes of Malmesbury (eleven volumes), ed. Sir William Molesworth. London: John Bohn. http://onlinebooks.library.upenn.edu/webbin/metabook?id=hobbesworks (accessed 20 Nov. 2011).

Hull, Charles Henry (ed.). 1899. The economic writings of Sir William Petty, together with the observations upon bills of mortality, more probably by Captain John Graunt (two volumes). Cambridge: Cambridge University Press.

Hunter, Michael. 1981. Science and society in Restoration England. Cambridge: Cambridge University Press.

James, David G. 1949. The age of reason: Hobbes, Locke, Bolingbroke. London: Longmans, Green, and Company.

Kargon, Robert. 1965. William Petty's mechanical philosophy. Isis, 26 (1): 63-66.

Kuhn, Thomas S. 1970 [1962]. The structure of scientific revolutions. Chicago: The University of Chicago Press.

Letwin, William. 1975 [1963]. The origin of scientific economics: English economic thought 1660-1776. Westport (CT): Greenwood Press.

Marx, Karl, and Frederick Engels. 1956 [1845]. The holy family or critique of critical critique. Moscow: Foreign Languages Publishing House.

Masson, Irvine, and Alexander J. Youngson. 1960. Sir William Petty F. R. S. (1623-1687). Notes and Records of the Royal Society of London, 15 (July): 79-90.

McCormick, Ted. 2009. William Petty and the ambitions of political arithmetic. New York: Oxford University Press.

Petty, Sir William. 1899 [1662]. A treatise of taxes and contributions. Reprinted in The economic writings of Sir William Petty, Vol. 1. Cambridge: Cambridge University Press, 1-97. http://files.libertyfund.org/files/1677/0605-01_Bk.pdf (accessed 20 Nov. 2011).

Petty, Sir William. 1899 [1690]. Political arithmetic. Reprinted in The economic writings of Sir William Petty, Vol. 1. Cambridge: Cambridge University Press, 233-313. http://files.libertyfund.org/files/1677/0605-01_Bk.pdf(accessed 20 November 2011).

Petty, Sir William. 1899 [1691]. Verbum sapienti. Reprinted in The economic writings of Sir William Petty, Vol. 1. Cambridge: Cambridge University Press, 99-120. http://files.libertyfund.org/files/1677/0605-01_Bk.pdf(accessed 20 November 2011).

Petty, Sir William. 1927. The Petty papers (two volumes), ed. from the Bowood papers by the Marquis of Landsdowne. London: Consable and Company Limited.

Petty, Sir William. 1969 [1674]. The discourse made before the Royal Society the 26 of November 1674. Concerning the use of duplicate proportion in sundry important particulars: together with a new hypothesis of springing or elastique motion. Reprinted in Early English books, 1641-1700. Ann Arbor (MI):University Microfilms Inc.

Petty, Sir William. 1990 [1648a]. The advice of W. P. to Mr. Samuel Hartlib for the advancement of some particular parts of learning. Reprinted in Early English books, 1641-1700. Ann Arbor (MI): University Microfilms Inc.

Petty, Sir William. 2002 [1648b]. Letter in scribble hand to Hartlib. In The Hartlib papers, S. Hartlib. Sheffield: Humanities Research Online, inventory reference 7.

Poovey, Mary. 1998. A history of the modern fact. Chicago: The University of Chicago Press.

Rattansi, P. N. 1968. The intellectual origins of the Royal Society. Notes and Records of the Royal Society of London, 23 (2): 129-143.

Sacksteder, William. 1980. Hobbes: the art of the geometricians. Journal of the History of Philosophy, 18 (2): 131-146. 
Shapin, Steven. 2010. Never pure. Baltimore: John Hopkins University Press.

Shapin, Steven, and Simon Schaffer. 1985. Leviathan and the air-pump: Hobbes, Boyle, and the experimental life. Princeton: Princeton University Press.

Skinner, Quentin. 1966. Thomas Hobbes and his disciples in France and England. Comparative Studies in Society and History, 8 (2): 153-167.

Spiegel, Henry William. 1991. The growth of economic thought. Durham: Duke University Press.

Strauss, Erich. 1954. Sir William Petty: portrait of a genius. London: The Bodley Head.

Talaska, Richard A. 1988. Analytic and synthetic method according to Hobbes. Journal of the History of Philosophy, 26 (3): 207-237.

Thornton, Henry. 2009. The genesis of macroeconomics. Oxford: Oxford University Press.

Ullmer, James H. 2004. The macroeconomic thought of Sir William Petty. Journal of the History of Economic Thought, 26 (3): 401-413.

Vickers, Brian. 1987. English science: Bacon to Newton. Cambridge: Cambridge University Press.

Webster, Charles. 1970. Samuel Hartlib and the advancement of learning. Cambridge: Cambridge University Press.

Webster, Charles. 1975. The great instauration: science, medicine, and reform, 16261660. London: Duckworth.

Wennerlind, Carl. 2003. Credit-money as the philosopher's stone: alchemy and the coinage problem in seventeenth-century England. History of Political Economy, 35 (Annual Supplement): 234-261.

James H. Ullmer is associate professor of economics at Western Carolina University. His main research interests are in the history of economic thought, especially the writings of seventeenth-century political economists, regional economics, and economic pedagogy. His recent publications include: "William Petty, Nicholas Barbon, multiples, and a new hypothesis of independent discovery" (2009); "The economic effects of Harrah's Cherokee casino and hotel on the regional economy of Western North Carolina" (2007, with Steve Ha); "The macroeconomic thought of Nicholas Barbon" (2007); "Threshold market analysis of Western North Carolina" (2006, with Steve Ha); "The macroeconomic thought of Sir William Petty" (2004); "The value of learning communities in the economics classroom" (2003, with April Lewandowski).

Contact e-mail: <Ullmer@wcu.edu>

Website: <http://paws.wcu.edu/ullmer $>$ 